УДК 378:141:371.134(043.3):355

DOI:

Клавдія Тушко, кандидат педагогічних наук, доиент кафедри педагогіки та соціально-економічних дисичилін Національна академія Державної прикордонної служби Украйни імені Богдан Хмельницького

\title{
СУТНІСТЬ ТА ЗМІСТ КОМПЕТЕНТНОСТЕЙ У ЗДІЙСНЕННІ ПРОФЕСІЙНОЇ ВЗАСМОДІЇ МАЙБУТНІМИ ОФІЦЕРАМИ-ПРИКОРДОННИКАМИ
}

У статті проаналізовано проблему забезпечення якісної професійної підготовки майбутніх офіцерівприкордонників та формування в них здатності до професійної взаємодї. Обтрунтовано важливість формування згаданої якості у фахівиів прикордонного відомства. Розкрито значення компетентнісного підходу у формуванні здатності до професійної взаємодї. Визначено зміст поняття "компетентність у реалізації професійної взаємодії майбутніми офіцерами-прикордонниками”. Здійснено детальний аналіз особливостей оперативно-служсової діяльності майбутніх офіщерів-прикордонників: суворий розподіл функціональних обов 'язків, регламентованість, авторитарність в управлінській ланці, неухильне виконання вимог статуту, обмеженість у прийнятті і реалізації управлінських рішень. Подано перелік професійних компетентностей узазначеній взаємодіi.

Ключові слова: майбутні офічери-прикордонники; професійна підготовка; професійна діяльність; професійна взаємодія; компетентність; професійні компетентності.

Jim. 15.

Klavdiya Tushko, Ph.D.(Pedagogy), Associate Professor of the Pedagogy and Socio-Economic Disciplines Department

National Academy of the State Border Guard Service of Ukraine named after Bohdan Khmelnytskiy

\section{ESSENCE AND CONTENT OF COMPETENCIES IN IMPLEMENTATION OF PROFESSIONAL INTERACTION BY FUTURE OFFICERS-BORDER GUARDS}

Formation of the ability to professionally interact between specialists of any specialty in modern society has taken a prominent place. The justification of the importance of forming the capacity for professional interaction in the system of professional training of future officers-border guards is possible on the basis of disclosure of the essence, content and varieties of relevant professional competencies. The preparation of future officers-border guards for professional interaction is possible through the implementation of the provisions of the main methodological approaches: systemic, synergetic, acmeological, axiological, person-oriented and competent.

Modern pedagogical theory and practice have significant gains from the problem of implementing a competent approach into the system of higher education.

The article analyzes the problem of providing the high-quality professional training of future officers-border guards and forming their ability to engage in professional interaction. The importance of forming the mentioned quality in the specialists of the border department is substantiated. The significance of the competence approach in the formation of the ability to engage in professional interaction is revealed. The content of the concept "competency in the implementation of professional interaction by future officers-border guards" is determined. A detailed analysis of the peculiarities of operational and service activities of future officers-border guards was made: strict distribution of functional responsibilities, regulation, and authoritarianism in the management chain, strict compliance with the statute's requirements, limited acceptance and implementation of managerial decisions. A list of professional competencies in the specified interaction is given.

Keywords: the future officers-border guards; professional training; professional activity; professional interaction; a competence; a professional competence.

П остановка проблеми в загальному вигляді. Формування здатності до професійної взаємодії фахівців будьякої спеціальності в сучасному суспільстві зайняло вагоме місце [10].

Обгрунтування важливості формування здатності до професійної взаємодії у системі професійної підготовки майбутніх офіцерівприкордонників можливе на підставі розкриття сутності, змісту та різновидів відповідних професійних компетентностей.

Підготувати майбугніх офіцерів-прикордонників до професійної взаємодії можливе завдяки реалізації положень основних методологічних підходів: системного, синергетичного, акмеологічного, аксіологічного, особистісноорієнтованого та компетентнісного.

Сучасна педагогічна теорія та практика мають 


\section{СУТНІСТЬ ТАЗМІСТ КОМПЕТЕНТНОСТЕЙУ ЗДІЙСНЕННІПРОФЕСІЙНОӤ ВЗАЄМОДІЇ МАЙБУТНІМИОФПЕРАМИ-ПРИКОРДОННИКАМИ}

суттєві напрацювання з проблеми реалізації компетентнісного підходу у системі вищої освіти [5].

Аналіз останніх досліджень та публікацій. Зарубіжні та вітчизняні теоретики і практики здійснювали дослідження або безпосередньо про формування здатності до професійної взаємодії, або дотичні до цієї проблеми аспекти: формування комунікативних навичок та вмінь, культури спілкування, комунікативної компетентності тощо. Варті уваги наукові праці таких дослідників як Л. Губенко [2] та М. Дороніна [3] (формування культури спілкування), Л. Дягілєва [4] (основи підготовки військовослужбовців до взаємодії із міжнародними організаціями); С. Коломієць [6] (підготовка майбутніх фахівців до взаємодії із представниками зарубіжних бізнес-структур); О. Мисечко [8] (технологія формування службового спілкування); Т. Сніца [12] (основи полікультурної компетентності); В. Чупира [13] (культура міжетнічного спілкування) та багато ін..

Формулювання мети статті. Сучасна педагогічна теорія та практика мають суттєві напрацювання 3 проблеми реалізації компетентнісного підходу у системі вищої освіти. Проте недостатньо вивчена проблема формування компетентності майбутніх офіцерівприкордонників у реалізації професійної взаємодії.

Виклад основного матеріалу. Популярність компетентнісного підходу у сучасному науковому обігуможна пояснити зміною вимог до підготовки майбутніх фахівців у закладах вищої освіти [1]. До цього твердження необхідно додати існування особливостей вищої військової освіти, що залежать від змісту зовнішньої та внутрішньої політики держави, зокрема нині на українських східних територіях відбувається війна.

Формування певного виду компетентності (професійної чи загальної) передбачає набуття певної якості інтегративного характеру, що містить і знання, і уміння, і сформовані навички, i особистісно-професійний досвід тощо [7].

Реалізація компетентнісного підходу в професійній підготовці майбутніх офіцерівприкордонників до професійної взаємодії усіх спеціальностей (безпека та охорона державного кордону, право, правоохоронна діяльність, психологія, філологія, автомобільний транспорт, телекомунікації та радіотехніка) полягає у формуванні та розвитку комплексу ключових компетентностей. Рівень сформованості цього комплексу свідчить про рівень сформованості здатності до професійної взаємодії.

Сучасна педагогічна наука використовує різні підходи щодо тлумачення змісту орієнтованої на компетентності освіти [11].
У представленомудослідженні компетентнісний підхід виступає як рівень оволодіння механізмами та технологіями взаємодії, досягнення успіхів у житті, якість життедіяльності у соціальних спільнотах, результатами та способами налагодження взаємовідносин тощо [9].

Отже, перед системою професійної підготовки майбутніх офіцерів-прикордонників стоїть завдання забезпечити впровадження таких форм, методів та засобів, що сприятимуть підвищенню iї якості [14].

Особливості професійної діяльності (оперативно-службової діяльності) майбутніх офіцерів-прикордонників, полягають у розподілі функціональних обов'язків, регламентованості, авторитарності в управлінській ланці, неухильному виконанні вимог статуту, обмеженості у прийнятті і реалізації певних рішень.

Фундаментом професійної діяльності офіцерівприкордонників $€$ виконання наступних функцій:

- організація та здійснення прикордонного контролю;

- контроль та пропуск транспортних засобів та осіб;

- зупинення нелегального переміщення транспорту та осіб через кордон;

- узгодження дій із військовими та правоохоронними структурами щодо захисту кордону;

- реалізація розвідувальної, інформаційноаналітичної та пошуково-розшукової діяльності щодо забезпечення цілісності держави;

- забезпечення участі у протидії кримінальним угрупуванням різних видів.

Комплексом завдань, що виконують офіцериприкордонники є завдання дотичні до охорони окремої ділянки кордону, зокрема: організація та здійснення прикордонного контролю та охорони кордону в окремому прикордонному загоні. Зазначене вище передбачає як автономну, так i злагоджену взаємодію з наявними органами охорони кордону.

Ще одним аспектом професійної діяльності є те, що майбугні офіцери-прикордонники укадровій системі прикордонного відомства належать, в першу чергу, до управлінської ланки. А це означає, що вони повинні приймати та обгрунтовувати управлінські рішення, забезпечувати злагодженість колективу прикордонників, створювати міцні зв'язки із мешканцями прикордонних регіонів, достойно представляти Україну перед громадянами іноземних держав тощо.

У проблемі формування здатності майбутніх офіцерів-прикордонників до професійної взаємодії необхідно забезпечити формування системи 


\section{СУТНІСТЬ ТАЗМІСТ КОМПЕТЕНТНОСТЕЙУ ЗДІЙСНЕННІПРОФЕСІЙНОЇ ВЗАЄМОДІЇ МАЙБУТНІМИОФЩЕРАМИ-ПРИКОРДОННИКАМИ}

професійних компетентностей з урахуванням різновидів цієї взаємодії, тобто:

- реалізація взаємодії з керівниками у системі iєpapxiï;

- реалізація взаємодії 3 колективом прикордонників;

- реалізація взаємодії з місцевим населенням прикордонного регіону;

- реалізація взаємодії з представниками органів місцевого самоврядування;

- реалізація взаємодії з військовими та правоохоронними формуваннями;

- реалізація взаємодії з громадянами іноземних держав, які перетинають державний кордон.

Подані вище професійні компетентності мають характеристику соціальних, пізнавальних, комунікативних, культурологічних, проте відображають практико-теоретичну здатність майбутніх офіцерів-прикордонників до реалізації професійної взаємодії. Таким чином, 3 урахуванням сутності причинно-наслідкових зв'язків дефініція “професійна компетентність майбутніх офіцерів-прикордонників щодо реалізації професійної взаємодії” випливає 3 поняття “професійна компетентність”, що в свою чергу, виплило з поняття "компетентність".

Отже, професійна компетентність майбутніх офіцерів-прикордонників щодо реалізації професійної взаємодії $є$ багатогранним та специфічним явищем, що є основою ефективного виконання професійних обов'язків; $є$ ціннісною системою щодо професійної взаємодії; високим рівнем усвідомлення та оволодіння системою знань, умінь та навичок; сформованістю характеристик щодо діалогічної діяльності; наявністю позитивної системи особистісних якостей.

Висновки. Можна констатувати, що компетентностями майбутніх офіцерівприкордонників щодо реалізації професійної взаємодії є результатом діалектичної єдності таких компонентів у структурі особистості, як природній та соціальний, а також зміст їх фахової підготовки та функціональних професійних завдань.

\section{ЛІТЕРАТУРА}

1. Глазкова І. Я. Теоретико-методичні засади формування у майбутніх учителів компетентності запобігання і подолання педагогічних бар'єрів у процесі професійної підготовки: дис. ... д-ра пед. наук: 13.00.04. Класичний приватний університет. Запоріжжя, 2013. 552 с.

2. Губенко Л. Г., Нємцов В.Д. Культура ділового спілкування: навч. посібник для студ. та ін. Київ, 2000. 200 с.
3. Дороніна М. С. Культура спілкування ділових людей: пос. для студ. гум. ф-тів ВНЗ. Вид. Дім "КМ Academia", 1997. 192 с.

4. Дягілєва Л. Д. Підготовка курсантів вищих навчальних закладів МВС України до роботи в міжнародних правоохоронних організаціях: автореф. дис. ... канд. пед. наук. Національна академія Державної прикордонної служби України імені Б. Хмельницького. Хмельницький, $2004.18 \mathrm{c}$.

5. Жидецький Ю. Сучасні проблеми професійного розвитку особистості. Педагогіка i психологія професійної освіти. 2002. № 2. С. $69-75$.

6. Коломієць С.С. Навчання спеціалістів професійно-орієнтованого спілкування із зарубіжними партнерами /на матеріалі англійської мови: дис. ... канд. пед. наук: 13.00.02. Київ, 1993. $162 \mathrm{c}$.

7. Маслов В. С. Теорія іпрактика культурологічної підготовки слухачів і курсантів вищих військових навчальних закладів освіти: автореф. дис. ... д-ра пед. наук. КВГІ МО України К., 1998. 36 с.

8. Мисечко О. В., Грязнов І. О. Застосування проблемного навчання при формуванні вмінь службового спілкування у курсантівприкордонників. Збірник наукових праць № 31 . Частина II. Хмельницький: Вид-во НАДПСУ, 2004. C. 139-142.

9. Морська Л. І. Формування вмінь професійного спілкування англійською мовою у студентів фізичного виховання: автореф. дис ... канд. пед. наук: 13.00.02. Київ, $2001.21 \mathrm{c}$.

10. Нечаєв Л. В. Підготовка студентів педінститутів до взаємодії з учнями: автореф. дис ... канд. пед. наук. Харків, 1991. 18 с.

11. Радченко С. Г. Готовність до професійної діяльності як проблема педагогіки. Гуманітарні науки і сучасність. Київ, 1999. С. 180 - 188.

12. Сніца Т. Є. Структурні компоненти полікультурної компетентності майбутніх офіцерівприкордонників. Педагогічна освіта: теорія і практика. 2013. Вип. 15. С. 100-105. URL: http:// nbuv.gov.ua/UJRN/znppo_2013_15_20.

13. Чупира В. В. Формування культури міжетнічного спілкування як соціальна проблема. Хмельницький: Вид-во АПВУ, 1996. $112 \mathrm{c}$.

14. Bredella L., Hornung A. Towards a Pedagogy of Intercultural Understanding. American Studies. 1992. № 37. P. 559-594.

15. Buttjes D., Byram M., Buttjes D. Mediating languages and cultures: the social and intercultural dimen-sion restored. Mediating Languages and Cultures. Towards an Intercultural Theory of 


\section{СУТНІСТЬ ТАЗМІСТ КОМПЕТЕНТНОСТЕЙ У ЗДЙСНЕННІПРОФЕСІЙНОЇ ВЗАЄМОДІЇ МАЙБУТНІМИОФІЦЕРАМИ-ПРИКОРДОННИКАМИ}

Foreign Language Education. Clevedon: Multilingual Matters, 1991. P. 3-16.

\section{REFERENCES}

1. Glazkova, I. Ya. (2013). Teoretyko-metodychni zasady formuvannia $\mathrm{u}$ maibutnikh uchyteliv kompetentnosti zapobihannia i podolannia pedahohichnykh barieriv u protsesi profesiinoi pidhotovky [Theoretical and methodical principles of formation of future competence teachers to prevent and overcome pedagogical barriers in the process of professional training]. Doctor's thesis. Classical private university. Zaporizia, 552 p. [in Ukrainian].

2. Gubenko, L. G. \& Nemtsov, V. D. (2000). Kultura dilovoho spilkuvannia: navch. posibnyk dlia stud. ta in. [Culture of business communication: Teaching student guide etc]. Kyiv, 200 p. [in Ukrainian].

3. Doronina, M. S. (1997). Kultura spilkuvannia dilovykh liudei: pos. dlia stud. hum. f-tiv VNZ. [Culture of communication of business people: Pos. for the stud rubber FTs of higher educational establishments]. House "KM Academia", 192 p. [in Ukrainian].

4. Diaghilev, L. D. (2004). Pidhotovka kursantiv vyshchykh navchalnykh zakladiv MVS Ukrainy do roboty $\mathrm{V}$ mizhnarodnykh pravookhoronnykh orhanizatsiiakh [Preparation of cadets of higher educational establishments of the Ministry of Internal Affairs of Ukraine for work in international lawenforcement organizations]. Extended abstract of candidate's thesis. National Academy of the State Border Guard Service of Ukraine named after B. Khmelnitsky. Khmelnitsky, 18 p. [in Ukrainian].

5. Zhidetskyy, Yu. (2002). Suchasni problemy profesiinoho rozvytku osobystosti [Modern problems of professional development of personality]. Pedagogics and psychology of vocational education. No. 2, pp. 69 - 75. [in Ukrainian].

6. Kolomiets, S. S. (1993). Spetsialistiv profesiinooriientovanoho spilkuvannia iz zarubizhnymy partneramy /na materiali anhliiskoi movy [Training of specialists of professional-oriented communication with foreign partners / on the material of English ]. Candidate's thesis. Kyiv, 162 p. [in Ukrainian].

7. Maslov, V. S. (1998). Teoriia i praktyka kulturolohichnoi pidhotovky slukhachiv i kursantiv vyshchykh viiskovykh navchalnykh zakladiv osvity [Theory and Practice of Cultural Training of Students and Cadets of Higher Military Educational Institutions of Education]. Extended abstract of Doctor's thesis. KVGI of the Ministry of Defense of Ukraine. Kyiv, 36 p. [in Ukrainian].

8. Mischeko, O. V. \& Gryaznov, I. O. (2004). Zastosuvannia problemnoho navchannia pry formuvanni vmin sluzhbovoho spilkuvannia u kursantiv-prykordonnykiv [Application of problembased education in the formation of skills of service communication with cadets-frontier guards]. Collection of scientific works. No. 31. Part II. Khmelnitsky, pp. 139-142. [in Ukrainian].

9. Morska, L. I. (2001). Formuvannia vmin profesiinoho spilkuvannia anhliiskoiu movoiu u studentiv fizychnoho vykhovannia [Formation of skills of professional communication in English to students of physical education]. Extended abstract of candidate's thesis. Kyiv, 21 p. [in Ukrainian].

10. Nechaev, L. V. (1991). Pidhotovka studentiv pedinstytutiv do vzaiemodii z uchniamy. [Preparation of students of pedagogical institutes for interaction with students]. Extended abstract of candidate's thesis. Kharkiv, 18 p. [in Ukrainian].

11. Radchenko, S. G. (1999). Hotovnist do profesiinoi diialnosti yak problema pedahohiky. [Readiness for professional activity as a problem of pedagogy]. The humanities and modernity. Kyiv, pp. 180 - 188. [in Ukrainian].

12. Sniza, T. Y. (2013). Strukturni komponenty polikulturnoi kompetentnosti maibutnikh ofitserivprykordonnykiv [Structural components of multicultural competence of future officers-border guards]. Pedagogical Education: Theory and Practice. Issue 15, pp. 100-105. Available at: http:// nbuv.gov.ua/UJRN/ znppo_2013_15_20. [in Ukrainian].

13. Chupira, V. V. (1996). Formuvannia kultury mizhetnichnoho spilkuvannia yak sotsialna problema [Formation of the culture of interethnic communication as a social problem]. Khmelnitsky, 112 p. [in Ukrainian].

14. Bredella, L. \& Hornung, A. (1992). Towards a Pedagogy of Intercultural Understanding. (ed.): American Studies. No. 37. pp. 559-594. [in English].

15. Buttjes, D., Byram, M. \& Buttjes, D. (1991). Mediating Languages and Cultures: The Restructured Social and Intercultural Dimension. Mediating Languages and Cultures. Towards an Intercultural Theory of Foreign Language Education. Clevedon: Multilingual Matters, 1991.pp. 3-16. [in English].

Стаття надійшла до редакції 14.03.2019

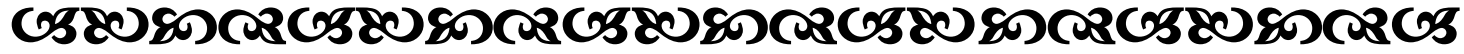

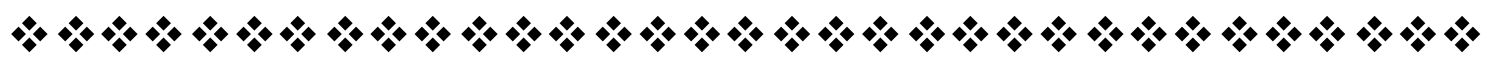

